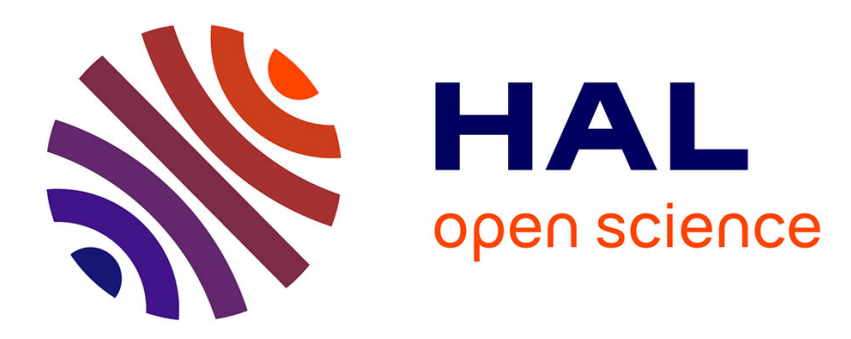

\title{
Corrosion in coal gasification atmospheres
}

Roger Perkins

\section{To cite this version:}

Roger Perkins. Corrosion in coal gasification atmospheres. Journal de Physique IV Proceedings, 1993, 03 (C9), pp.C9-697-C9-706. 10.1051/jp4:1993973 . jpa-00252414

\section{HAL Id: jpa-00252414 https://hal.science/jpa-00252414}

Submitted on 1 Jan 1993

HAL is a multi-disciplinary open access archive for the deposit and dissemination of scientific research documents, whether they are published or not. The documents may come from teaching and research institutions in France or abroad, or from public or private research centers.
L'archive ouverte pluridisciplinaire HAL, est destinée au dépôt et à la diffusion de documents scientifiques de niveau recherche, publiés ou non, émanant des établissements d'enseignement et de recherche français ou étrangers, des laboratoires publics ou privés. 


\title{
Corrosion in coal gasification atmospheres $(*)$
}

\author{
Roger A. Perkins \\ Consultant, 1142 Lincoln Dr., Mtn.View, CA, 94040, U.S.A.
}

\begin{abstract}
Corrosion of metallic materials by coal gasification atmospheres has been the subject of extensive study for over 20 years. While many alloys were found to be resistant to attack by high moisture content gases representative of fluidized bed gasifiers at temperatures up to $900{ }^{\circ} \mathrm{C}$, good resistance could not be sustained for more than a few thousand hours as a result of changes in the structure and composition of oxide scales. A shift to use of entrained slagging gasifiers by the electric power industry during the past 12 years has largely eliminated the need for metallic materials to operate above $600^{\circ} \mathrm{C}$. However, the moisture content of the gas has been reduced greatly and nearly all materials form non-protective sulfide/oxide scales and can have high rates of surface recession, even at low temperatures. The challenge for the 90's is to develop a basic understanding of factors controlling the rate of surface recession in such atmospheres and to develop new alloys that will have adequate resistance to attack. Research should be directed to the effect of alloy and gas composition on corrosion mechanisms and kinetics in low moisture gas representative of entrained slagging gasification at high temperature reacting with metal surfaces at temperatures of $300-600^{\circ} \mathrm{C}$.
\end{abstract}

\section{Introduction.}

The gasification of coal to form a combustible gas with a useful heating value is not new. A variety of processes has been in use since the late 1800's to produce gas from coal. The processes were conducted at low pressure using insulated or cooled metallic components, and corrosion, by and large, was not viewed as a serious problem. In the early 1970's, a world energy crisis was encountered based on the belief that oil-based fuels were limited in supply and were becoming expensive. The United States embarked on a major effort to develop synthetic natural gas (syngas) and oil from coal to provide a basis for energy independence. New gasification processes were devised to produce fuels of high heating value or to be suitable for conversion to methane-based fuels as a substitute for natural gas.

The processes considered most promising were based on fluidized bed gasification in large insulated pressure vessels at high temperature and pressure. The systems required a wide range of internal metallic components including cyclones, transfer lines, plumbing, valves, diplegs, and supports to be exposed to the gasifier atmosphere at temperatures to $1000^{\circ} \mathrm{C}$ and pressures to $68 \mathrm{~atm}$. It soon became apparent that normal low alloy and stainless steels were subject to accelerated corrosion by sulfidation under these conditions. Little information was available on the reaction of materials with the complex atmospheres being generated and useful guidelines did not exist for selection of materials.

(*) Keynote lecture. 


\section{Technical background.}

In 1972, the American Gas Association (AGA) contracted the Metal Properties Council (MPC) to start a test program on the reaction of commercial alloys with advanced process coal gasification atmospheres [1]. The IIT Research Institute (IITRI) in Chicago, Il, was selected as a subcontractor to design, construct, and operate high pressure test facilities that could simulate the gasification environment. Corrosion testing began in 1973 and continued uninterrupted through 1985. Funds were augmented by the Department of Energy (DOE) and Gas Research Institute (GRI). New facilities were added, including corrosion/erosion test rigs at IITRI and tensile-creep-rupture test rigs at the Southwest Research Institute (SWRI) in San Antonio, TX. On conclusion of the test program, over $176000 \mathrm{~h}$ of corrosion tests had been conducted at temperatures of $482-1010^{\circ} \mathrm{C}$ on 88 different commercial alloys and coatings [1].

The majority of tests in the MPC program were conducted in a gas composition typical of an oxygen blown high-Btu fluidized bed gasifier prior to methanation to form a high-Btu syngas (Tab. I). A few tests also were conducted in a low Btu gas typical of an air blown gasifier (Tab. I). It was found that the majority of materials either could not form or could not sustain the growth of protective oxides in the baseline MPC atmosphere at temperatures above $650^{\circ} \mathrm{C}$. Many of the stainless steels with $18 \%$ or more $\mathrm{Cr}$ corroded at rates of $<0.05 \mathrm{~mm} / \mathrm{y}$ at $650^{\circ} \mathrm{C}$ while at $815^{\circ} \mathrm{C}$ or higher the rates exceeded $0.5 \mathrm{~mm} / \mathrm{y}$ and increased rapidly with increasing temperature. Alloys containing $>25 \% \mathrm{Cr}$ such as Stellite $6 \mathrm{~B}$ and IN671 were able to form protective chromia scales at temperatures above $650{ }^{\circ} \mathrm{C}$. However, after a few thousand hours of exposure the oxides broke down and rapid corrosion occurred, ending the useful life of components. The time to onset of breakaway could not be predicted and component reliability could not be assured. Breakaway corrosion was identified as the major life limiting factor for components at temperatures above $650^{\circ} \mathrm{C}$ and no materials were identified as having adequate resistance for long term service above this temperature.

The MPC program was largely a testing program and few of the resources were dedicated to analysis of the results or investigative studies to identify failure modes and mechanisms. The results of the limited work indicated that changes in the composition of the oxide scale and $\mathrm{Cr}$ depletion of the alloy below the scale/metal interface were responsible for breakaway. Time to onset of breakaway was found to be affected by Cr content of the alloy, temperature, pressure, and gas composition (notably sulfur potential) [1]. The data collected were not sufficient to construct a reliable model for prediction.

Table I. - Representative Coal Gasification Atmospheres.

\begin{tabular}{|c|c|c|c|c|c|c|c|c|}
\hline & & \multicolumn{4}{|c|}{ Volume Percent } & Ratio & \multicolumn{2}{|c|}{$\log \mathrm{P}_{\mathrm{O} 2}$} \\
\hline Time Period & Process Type & $\underline{\mathrm{H}}_{2}$ & $\underline{\mathrm{H}}_{2} \mathrm{O}$ & $\mathrm{CO}$ & $\underline{\mathrm{CO}}_{2}$ & $\underline{\mathrm{CO}}_{2}: \mathrm{CO}$ & $1144 \mathrm{~K}$ & $823 \mathrm{~K}$ \\
\hline $1970-1980$ & $\begin{array}{l}\text { FBG- MPC Hygas } \\
\text { - MPC Low BTU }\end{array}$ & $\begin{array}{l}24 \\
12\end{array}$ & $\begin{array}{c}39 \\
8\end{array}$ & $\begin{array}{l}18 \\
20\end{array}$ & $\begin{array}{c}12 \\
8\end{array}$ & $\begin{array}{l}0.667 \\
0.40\end{array}$ & $\begin{array}{l}-16.96 \\
-17.40\end{array}$ & $\begin{array}{l}-27.15 \\
-27.59\end{array}$ \\
\hline 1980-pres. & $\begin{array}{l}\text { ESG- Wet } \\
\text { - Dry }\end{array}$ & $\begin{array}{l}30 \\
32\end{array}$ & $\begin{array}{l}14 \\
--\end{array}$ & $\begin{array}{l}44 \\
64\end{array}$ & $\begin{array}{c}10 \\
4\end{array}$ & $\begin{array}{l}0.227 \\
0.063\end{array}$ & $\begin{array}{l}-17.89 \\
-19.01\end{array}$ & $\begin{array}{l}-28.08 \\
-29.21\end{array}$ \\
\hline
\end{tabular}


In 1976, The Electric Power Research Institute initiated a broad program of research on the corrosion/erosion of materials in coal gasification and combustion environments. Most of the contracts were investigative in nature and were designed to provide a much needed understanding of factors controlling behavior in these complex atmospheres. A number of factors controlling the formation and breakdown of protective oxide scales in coal gasification atmospheres were identified in a four year basic study of corrosion chemistry by the Lockheed Missiles \& Space Co. [2, 3]. It was found that a transition in behavior occurred as a function of the $\mathrm{Gr}$ content of an alloy and the equilibrium pressures of oxygen and sulfur in the gas at a given temperature. As shown in figure $1, \mathrm{Cr}$-rich oxide scales are formed to the right of the boundary while Fe/Ni-rich sulfide scales are formed to the left of the boundary. The boundary is shifted to higher sulfur and lower oxygen pressures as the $\mathrm{Cr}$ content of an alloy is increased. The equilibrium sulfur and oxygen pressure of the MPC test gas as plotted in figure 1 lies close to the boundary for alloys with $25 \% \mathrm{Cr}$. These are marginal oxide formers at $871^{\circ} \mathrm{C}$ in the MPC gas. Alloys with $45-50 \% \mathrm{Cr}$ can readily form protective chromia scales under the same conditions.

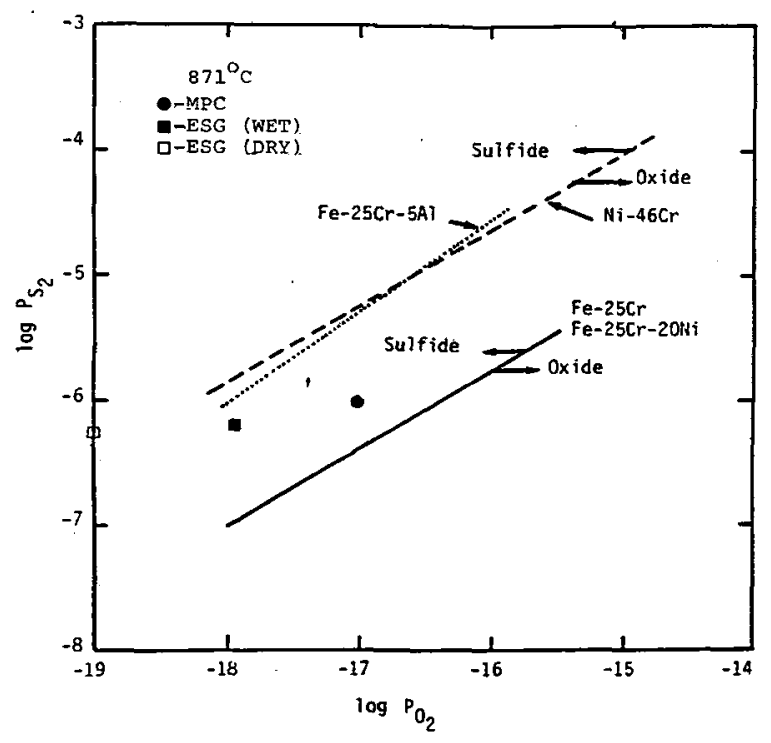

Fig. 1. - Oxide/sulfide transition boundaries for high alloy steels at $871^{\circ} \mathrm{C}$.

Initially, it was believed that the oxide/sulfide transition boundaries were related to the thermodynamic stability of oxide and sulfide condensed phases in the gas. However, as shown in figure 2A, the transition boundaries and the MPC gas equilibrium sulfur and oxygen pressures lie well within a phase field where chromium oxide would be a stable phase in equilibrium with the gas. Tests with unalloyed $\mathrm{Cr}$ confirmed that chromia scales indeed were formed on the surface but that sulfide particles formed at the scale metal interface and penetrated into the metal. Behavior was identical to that observed with $\mathrm{Ni}-50 \% \mathrm{Cr}$ alloys. However, $\mathrm{Cr}$ oxide was not formed on many alloys with $<50 \% \mathrm{Cr}$ under all conditions where it would be expected to be a stable phase in equilibrium with the gas. The scales formed on iron-base alloys with $25 \%$ or more $\mathrm{Cr}$ often contained large amounts of $\mathrm{Fe}$ and $\mathrm{Mn}$ in a complex $\mathrm{Cr}$-rich 


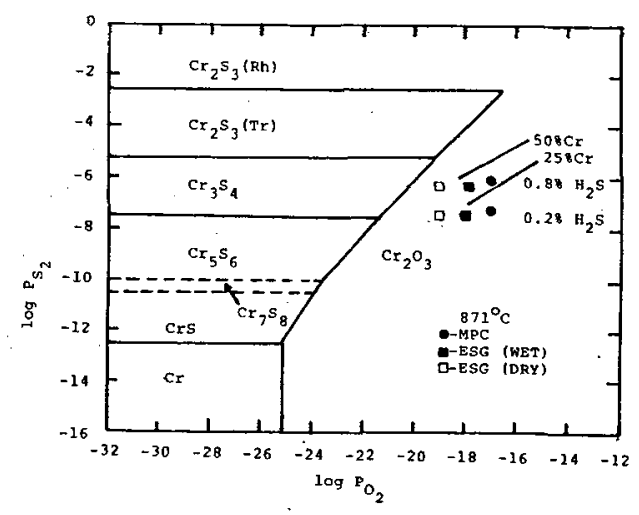

A- Phase Stability $871^{\circ} \mathrm{C}$

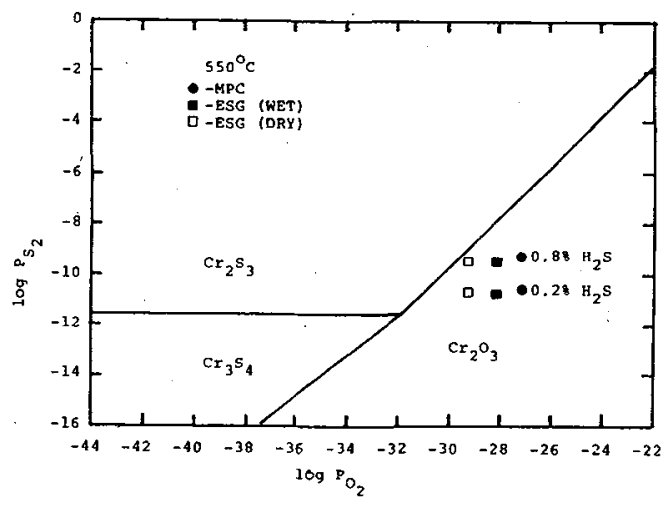

B- Phase Stability at $550^{\circ} \mathrm{C}$

Fig. 2. - Cr-O-S system phase stability at 871 and $550{ }^{\circ} \mathrm{C}$ relative to typical gasifier atmospheres.

oxide. Sulfide scales rich in Fe and Ni formed on the surface in gas compositions to the left of the transition boundaries (Fig. 1).

Sulfides were not found in the simple or complex oxide scales formed in the oxide stable region (Fig. 1) but were always detected at the scale/metal interface and in the underlying alloy. Sulfide particles formed preferentially at alloy grain and twin boundaries below the oxide scale. They were detected after only a few minutes exposure of a bare surface to the gas. The oxide scales were found to be permeable to sulfur and the size and number of sulfide particles increased with continued exposure. Detailed nucleation and growth studies revealed that the oxide/sulfide transition boundaries were defined by the kinetics of oxidation and sulfidation reactions $[2,3]$.

The boundary is determined by the effect of oxygen and sulfur pressures in the gas, $\mathrm{Cr}$ activity in the alloy, and temperature on the relative nucleation and growth rates of the various sulfide and oxide condensed phases that can be in equilibrium with the gas. If the rate of oxide growth is sufficiently fast, protective oxide scales can be formed, cutting off the growth of sulfide scales. Sulfidation is then controlled by transport through the oxide. If the rate of sulfide growth greatly exceeds that of oxide growth, external sulfide scales are formed instead. The sulfide scales will be molten at temperatures above $650^{\circ} \mathrm{C}$ on alloys rich in $\mathrm{Fe}$ and $\mathrm{Ni}$, resulting in greatly accelerated rates of sulfidation (catastrophic corrosion). These observations and conclusion subsequently were confirmed by independent studies conducted at the Argonne National Laboratories [4].

It was found that permeability of chromia scales to sulfur was dependent on the conditions under which the scales were formed [2]. Chromia scales formed in $\mathrm{H}_{2}-\mathrm{H}_{2} \mathrm{O}$ in the absence of sulfur were not permeable to sulfur on subsequent exposure to a syngas atmosphere high in $\mathrm{H}_{2} \mathrm{~S}$. This raised the hope that good resistance to sulfidation could be provided by controlled preoxidation of alloys. Detailed studies conducted by Lockheed for EPRI revealed that chromia scales formed in the absence of sulfur could provide protection in a high sulfur potential gas for up to $2000 \mathrm{~h}$ at $871^{\circ} \mathrm{C}$ (Fig. 3). The oxide continued to grow but eventually broke down, allowing liquid $\mathrm{Fe} / \mathrm{Ni}$ sulfide slags (molten) to form on the surface. Sulfides were not detected in the oxide scale or at the scale metal interface and bulk transport did not appear to be occurring. Instead, breakdown appeared to be the result of void formation or rupture 


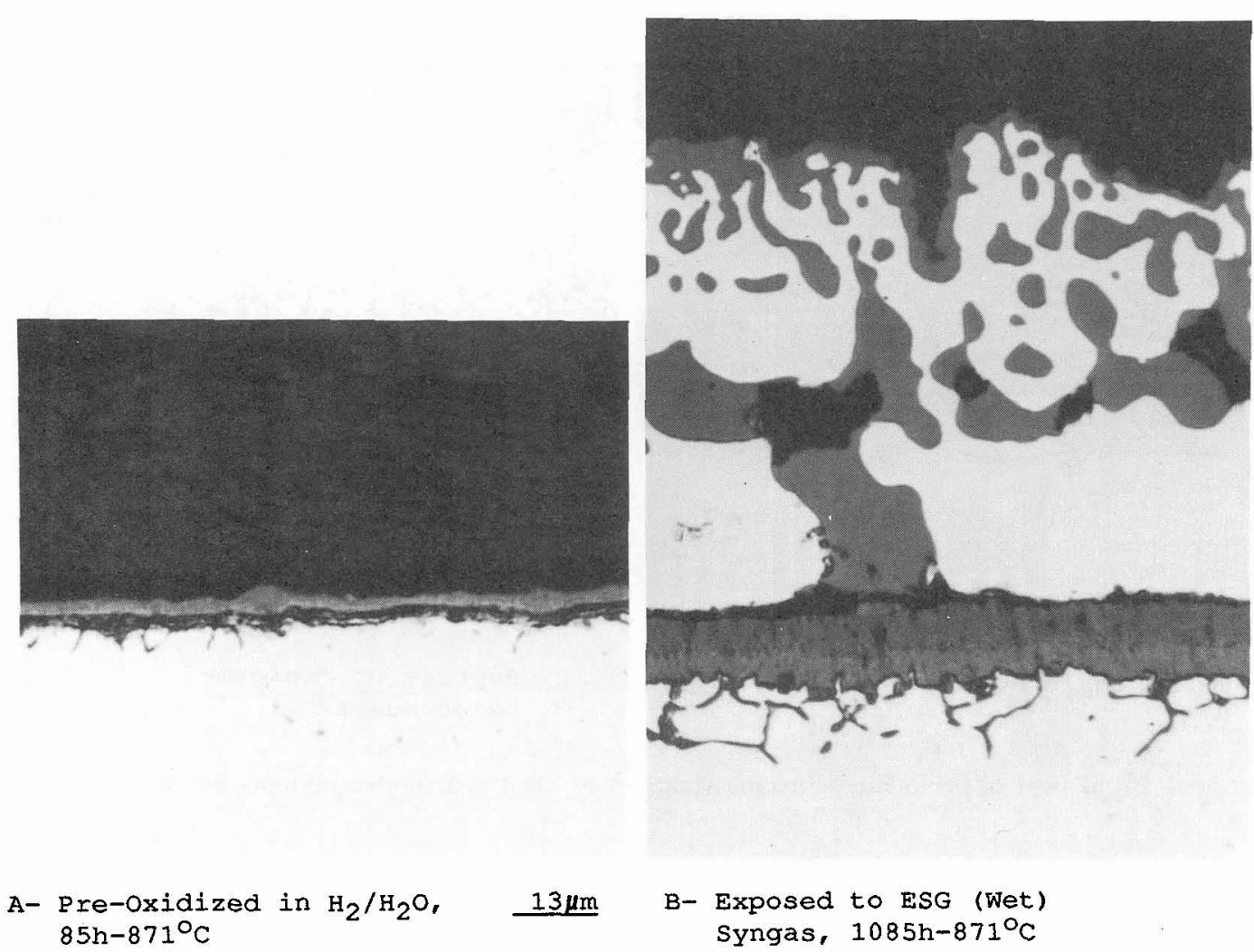

Fig. 3. - Breakaway of preformed chromia scales on $310 \mathrm{SS}$ at $871^{\circ} \mathrm{C}$.

of the scale which allowed sulfur rich gas to penetrate to the interface at random sites.

Studies with binary Fe-Cr alloys revealed that sulfides also nucleated and grew on the surface of preformed chromia scales as shown in figure $4 \mathrm{~A}$. In this case, the outward diffusion of $\mathrm{Fe}$ in the chromia scale resulted in the nucleation of $\mathrm{Fe}-\mathrm{Cr}$ sulfides on the surface. Sulfide nodules formed on the surface and eventually ruptured the scale as shown in figure 4B. While preoxidation can produce scales that will be good barriers to the inward transport of sulfur, the outward diffusion of base metal ions cannot be stopped. The scales will continue to grow and change in composition, eventually breaking down to permit rapid sulfidation at temperatures above $650^{\circ} \mathrm{C}$.

\section{Current status and future needs.}

In the late 1970 's, the electric power industry began a drive to generate electricity from clean gas produced from coal. The desire was for smaller plants and vessels that would produce a clean, combustible syngas based mainly on $\mathrm{H}_{2}$ and $\mathrm{CO}$ without residual toxic hydrocarbons. To achieve this goal, coal must be gasified at high temperature, above the melting point of coal ash, usually $1300-1600^{\circ} \mathrm{C}$. The process type most commonly used is entrained slagging gasification (ESG). Two types of processes are ready for commercial use today: 1) water/coal 

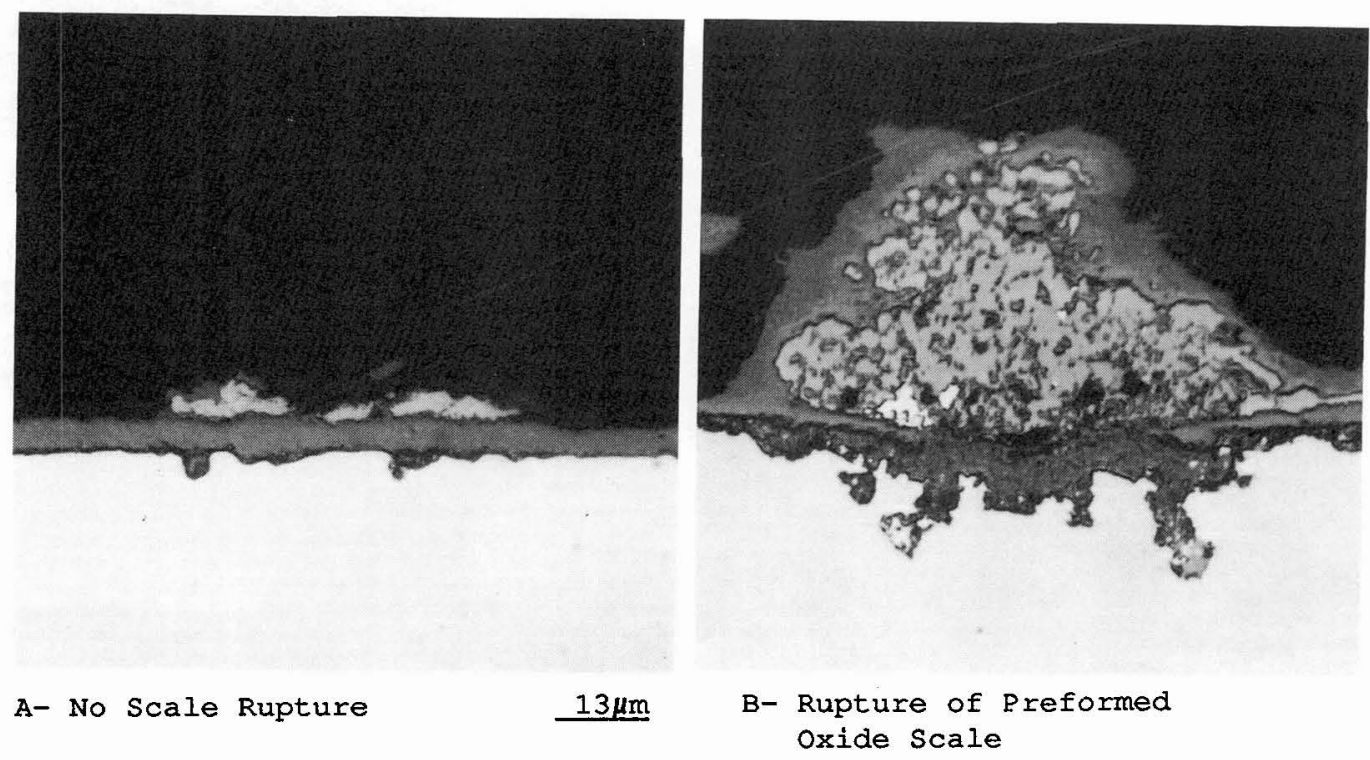

Fig. 4. - Breakaway of preformed chromia scales on Fe-26Cr in ESG (wet) syngas, $599 \mathrm{~h}-871^{\circ} \mathrm{C}$.

slurry feed processes that generate a gas with $15-25 \%$ steam and 2) a dry coal feed process that produces a gas containing $<1 \%$ steam. Typical gas compositions are shown in table $\mathbf{I}$. The gas will contain $0.1-1 \% \mathrm{H}_{2} \mathrm{~S}$ depending on the sulfur content of the coal feed.

Gasification in the entrained mode produces a very clean gas that does not require a subsequent methanation process or shift to increase the heating value. The process is done at high pressures in a very small vessel and does not require the use of uncooled metallic internal components. Metallic materials are used down stream of the gasifier in the form of heat exchangers that generate, and sometimes superheat steam as the product syngas is cooled for subsequent combustion in a turbine. The maximum metal temperature is about $550{ }^{\circ} \mathrm{C}$ based on requirements for producing superheated steam.

Alloys with up to $50 \% \mathrm{Cr}$ and pure $\mathrm{Cr}$ form external sulfide scales when exposed to the ESG syngas with or without steam at $300-550{ }^{\circ} \mathrm{C}$ as the outer sulfide scale, which on Fe-base alloys always is in the form of $\mathrm{FeS}$. As indicated in figure $2 \mathrm{~A}$, the gas compositions based on non-equilibrium calculations of $\log P_{\mathrm{O} 2}$ derived from the $\mathrm{CO}_{2} / \mathrm{CO}$ ratios in the input gas are still in the phase stability area where $\mathrm{Cr}_{2} \mathrm{O}_{3}$ would be a stable phase but are further to the left of the oxide/sulfide transition boundaries at $871^{\circ} \mathrm{C}$. By comparing figures $5 \mathrm{~A}$ and $5 \mathrm{~B}$ it can be seen that as temperature is reduced, the phase stability boundaries and gas compositions shift in the same directions and hold the same relative positions. However, the effect of temperature on the position of the oxide/sulfide transition boundaries has not been determined. Since these boundaries are established by kinetics, it is very likely that they move to the right (higher $\log P_{\mathrm{O} 2}$ ) as temperature is reduced. It is clear from the behavior of pure $\mathrm{Cr}$ and $\mathrm{Ni}-50 \mathrm{Cr}$ in the ESG wet gas at $500{ }^{\circ} \mathrm{C}$ that the transition boundaries have shifted considerably to the right.

Protective oxide scales cannot be formed on Cr-rich alloys at $550^{\circ} \mathrm{C}$ in the ESG wet process syngas as the result of kinetic rather than thermodynamic considerations. Kinetics of 


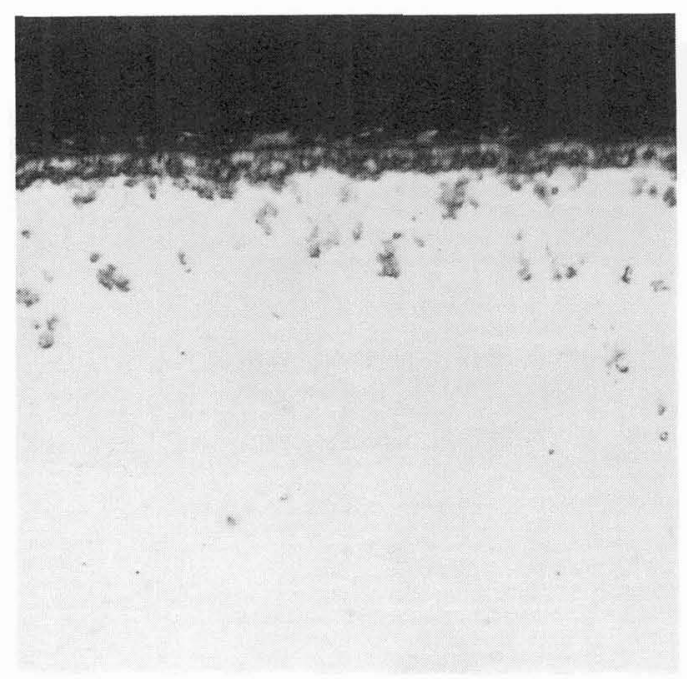

A- $310 \mathrm{SS}$

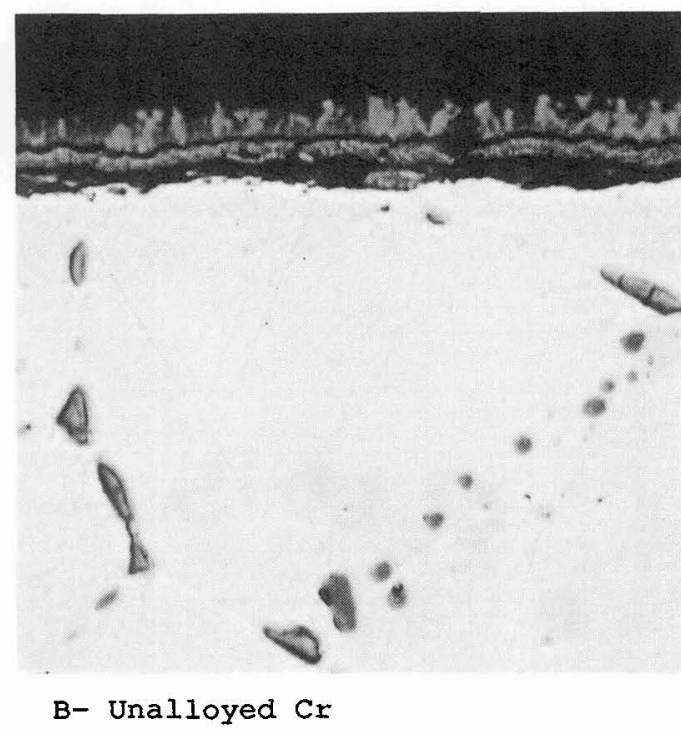

Fig. 5. - Sulfidation/oxidation of $310 \mathrm{SS}$ and $\mathrm{Cr}$ in ESG (wet) syngas, $600 \mathrm{~h}-550^{\circ} \mathrm{C}$.

sulfidation now becomes the major factor controlling useful life.

Based on results of laboratory tests, the rate of sulfidation of high $\mathrm{Cr}$ alloys in the wet process ESG gas at $300-550{ }^{\circ} \mathrm{C}$ is low and alloys such as $310 \mathrm{SS}$ appear to have adequate resistance for long term service, at least at lower temperatures in the range of $300-400^{\circ} \mathrm{C}$ [5]. Pack aluminized steels form protective alumina scales under these conditions, and based on initial tests in the wet ESG gas at $1 \mathrm{~atm}$. pressure, appeared to offer considerable promise for use in syngas coolers. However, plant experience revealed that aluminized steels were attacked rapidly and laboratory testing did not adequately simulate the plant conditions [6].

During the past ten years, the Lockheed Missiles \& Space Co. and EPRI have been conducting a systematic investigation of the effect of testing variables on behavior of materials in syngas cooler atmospheres. Variables under study included cyclic operation, gas pressure, $\mathrm{H}_{2} \mathrm{~S}$ partial pressure, slag deposits, $\mathrm{HCl}$ in syngas, gas-metal temperature differentials, component geometry and stress, and downtime corrosion. Detailed results are presented in two EPRI reports (EPRI GS-6971 and EPRI AP-5966) and have been summarized in two publications [6,7].

Each of the variables, either singly or in combination was found to have a significant effect. Three variables having the greatest effect were found to be the addition of $\mathrm{HCl}$ to the test gas, high pressure, and downtime corrosion. Results of plant exposures, including accelerated attack of aluminized steels, were duplicated when these variables were incorporated in laboratory tests. Tests at atmospheric pressure modified with $\mathrm{HCl}$ additions, slag deposits, and high $\mathrm{H}_{2} \mathrm{~S}$ partial pressures are useful for screening of materials behavior but will not adequately indicate in-plant behavior for many materials. Fully integrated testing at high pressure with $\mathrm{HCl}$ additions, deposits, and cyclic exposure with intermediate exposures to downtime corrosion in moist air are required for an in-depth evaluation of behavior in the laboratory.

The most recent development in the corrosion of materials in gasification atmospheres has 


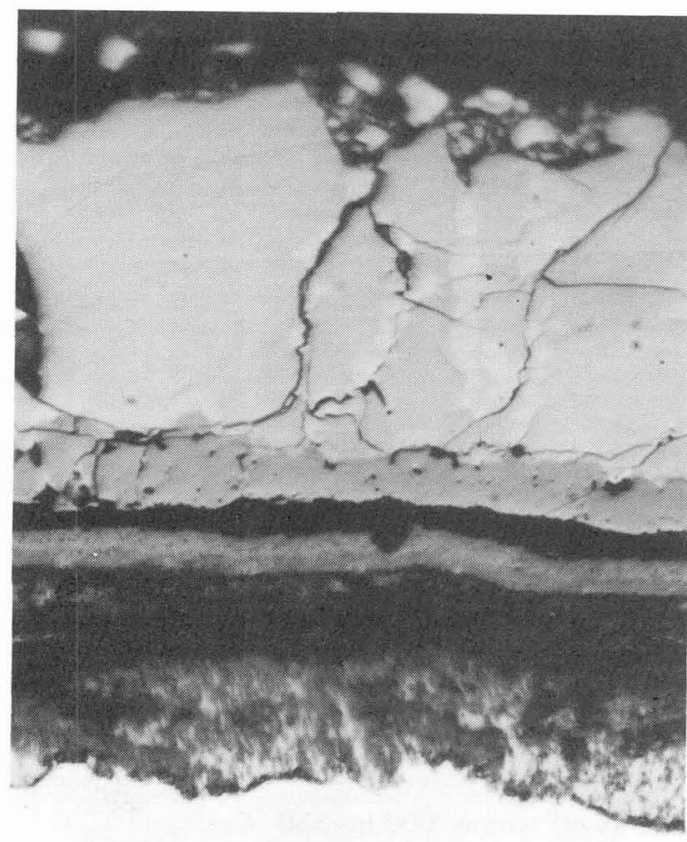

A- $600 \mathrm{~h}-550^{\circ} \mathrm{C}, 0.2 \% \mathrm{H}_{2} \mathrm{~S}$

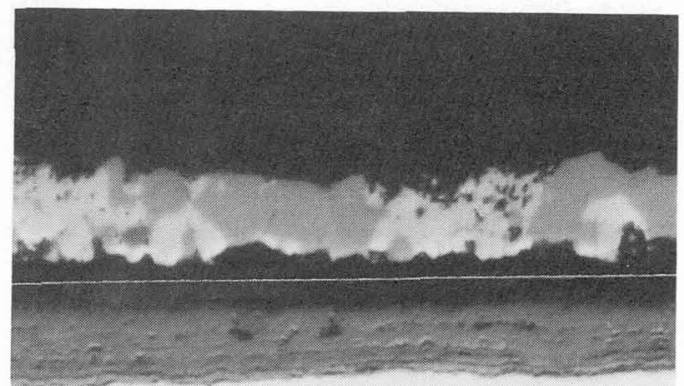

Fig. 6. - Sulfidation/oxidation corrosion of 310 SS in ESG (dry) syngas at $400-550^{\circ} \mathrm{C}$.

occurred with the introduction of ESG syngas with $<1 \%$ steam [8]. A typical gas composition is given in table $\mathrm{I}$. As shown in figure $2 \mathrm{~B}$, the gas composition is still in the same relative position as the ESG gas with water but is closer to the phase stability boundary in the Cr-O-S system. The reaction products formed are similar in both gases but the rates of reaction are different. As shown in figure 6, thick external sulfide scales and internal sulfide/oxide scales are formed on $310 \mathrm{SS}$ in the dry process syngas at $400-550^{\circ} \mathrm{C}$. The same material exposed to the wet process gas forms very thin layers of the same type of reaction products (Fig. 5A). Surface recession rates are significantly higher in the dry process gas [8].

The challenge for the future in materials for syngas coolers is in the modification of alloys or coatings to reduce the rates of sulfidation in low water content syngas. One approach being explored is the addition of refractory metal elements to steels [8-10]. Metals such as Mo, V, Nb, and Ti form sulfide scales in ESG wet and dry gases at all temperatures and have very slow rates of sulfidation. Segregation of these elements at a scale/metal interface as the result of local depletion in other elements or selective reaction with sulfur might slow the rate of sulfidation of high alloy steels. Tests in ESG wet gas have shown additions of 2-4\% $\mathrm{V}$ to the austenitic Fe-Cr-Ni steels to be particularly effective (Fig. 7B). Additions of Mo in some cases appear to be detrimental based on tests of commercial alloys modified with the addition of 2-4\% Mo. (Fig. 7A). Additions of Nb have been shown to increase resistance to sulfidation at higher temperatures [10].

Research in this area is in a very early stage and some anomalies in behavior are being 


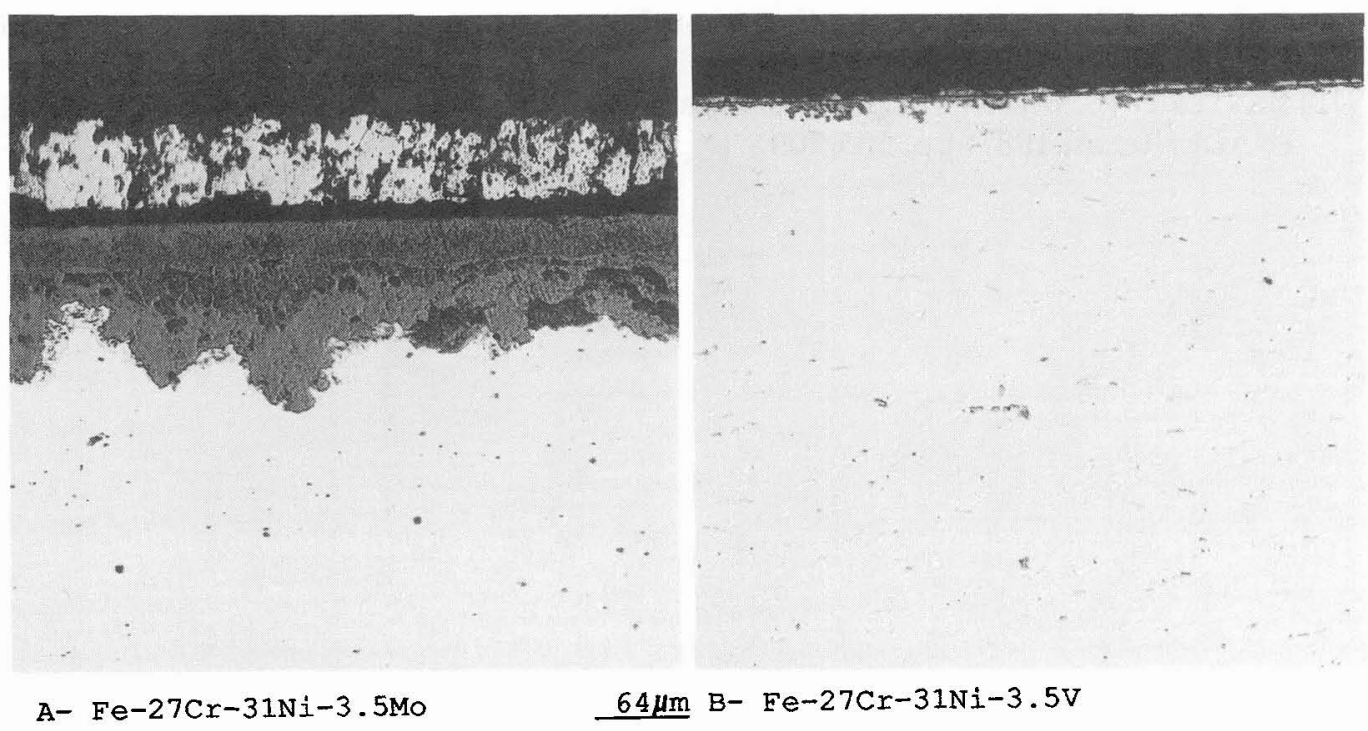

Fig. 7. - Relative sulfidation resistance of austenitic stainless steels modified with Mo and V to ESG (wet) syngas, $996 \mathrm{~h}-550^{\circ} \mathrm{C}$.

encountered. A study of mechanisms and rate controlling factors with respect to kinetics of sulfidation as a function of alloy composition and exposure conditions is needed. Analyses of the complex oxide-sulfide scales that are formed in ESG gases at of $300-550^{\circ} \mathrm{C}$ are needed to identify key components in the scales that govern transport processes and surface recession.

\section{References}

[1] Howes M.A.H., Materials for Coal Gasification, W.T. Bakker, S. Dapkunas, V. Hill Eds. (ASM International, Ohio, 1988) pp. 9-18.

[2] Perkins R.A., Environmental Degradation of High Temperature Materials, Series 3, No. 13, V2 (The Institution of Metallurgists, London, 1980) pp. 5-1, 5-17.

[3] Perkins R.A., High Temperature Corrosion (NACE-6, Texas, 1983)

[4] NateSAN K., Materials for Coal Gasification, W.T. Bakker, S. Dapkunas, V. Hill, Eds. (ASM International, Ohio, 1988) pp. 137-146.

[5] Perkins R.A., Corrosion Resistant Materials for Coal Gasification Systems, D.B. Meadowcroft, M.J. Manning Eds. (Applied Science Publishers, London, 1983) pp. 219-258.

[6] Bakker W.T., Perkins R.A., van Lierre J., Mater. Perf. 1 (1985) 9-17.

[7] PERkins R.A., BAKkeR W.T., Materials for Coal Gasification, W.T. Bakker, S. Dapkunas, V. Hill Eds. (ASM International, Ohio, 1988) pp. 85-96.

[8] BAKkeR W.T., PERKInS R.A., Heat Resistance and Materials (ASM International, Ohio, 1992- in press). 
[9] BAKkeR W.T., Perkins R.A., Corrosion-Erosion Wear of Materials, A.V. Levy Ed. (NACE, Texas, 1991) pp. 2-1, 2-29.

[10] BaXter D.J., NATESAn K., Proc. Corrosion-Erosion-Wear of Materials, A.V. Levy Ed. (NACE, Texas, 1987) pp. 305-309. 